\title{
Efficacy and outcomes of transobturator tension- free vaginal tape with or without concomitant pelvic floor repair surgery for urinary stress incontinence: five-year follow-up
}

\author{
Tracy SM Law *, Rachel YK Cheung, Tony KH Chung, Symphorosa SC Chan
}

\section{A B S T R A C T}

Objectives: To compare the 5-year subjective and objective outcomes of transobturator tensionfree vaginal tape alone versus the same procedure with concomitant pelvic floor repair surgery for pelvic organ prolapse in women with urinary stress incontinence.

Design: Prospective cohort study.

Setting: Urogynaecology unit at a university hospital in Hong Kong.

Patients: Of 218 women, 96 (44\%) received transobturator tension-free vaginal tape alone and 122 (56\%) received transobturator tension-free vaginal tape with concomitant pelvic floor repair surgery from September 2004 to December 2009. The women were followed up annually for up to 5 years after the operation.

Main outcome measures: The 5-year subjective and objective cure rates were assessed. Subjective cure was defined as no urine loss during physical activity and objective cure was defined as no urine leakage on coughing during urodynamic study.

Results: Overall, 88 women receiving transobturator tension-free vaginal tape alone and 101 women receiving transobturator tension-free vaginal tape with concomitant pelvic floor repair surgery subjective and objective cure rates of the two groups were $70.5 \%$ versus $94.1 \%(\mathrm{P}<0.01)$ and $80.3 \%$ versus $85.7 \%(\mathrm{P}=0.58)$, respectively.

Conclusions: Transobturator tension-free vaginal tape is an effective treatment for urinary stress incontinence in women who received it alone or with concomitant pelvic floor repair surgery for pelvic organ prolapse, providing high subjective and objective efficacy for up to 5 years after operation. Transobturator tension-free vaginal tape with concomitant pelvic floor repair surgery achieved similar, if not better, long-term outcome compared with transobturator tension-free vaginal tape alone.

\section{Hong Kong Med J 2015;21:333-8}

DOI: $10.12809 / \mathrm{hkmj} 144397$

TSM Law *, MB, ChB

RYK Cheung, FHKCOG, FHKAM (Obstetrics and Gynaecology)

TKH Chung, MD

SSC Chan, FHKCOG, FHKAM (Obstetrics and Gynaecology)

Department of Obstetrics and Gynaecology, The Chinese University of Hong Kong, Prince of Wales Hospital, Shatin, Hong Kong

* Corresponding author: tracylaw@cuhk.edu.hk

This paper was presented at the 4th Annual Scientific Meeting of the Obstetrical and Gynaecological Society of Hong Kong (ASM OGSHK) 25 May 2014, Hong Kong

New knowledge added by this study

Transobturator tension-free vaginal tape (TO-TVT) is an effective treatment for urinary stress incontinence in women who received it alone or with concomitant pelvic floor repair surgery for pelvic organ prolapse (POP).

\section{Introduction}

Urinary stress incontinence (USI) is a common distressing problem affecting women worldwide. The prevalence of USI ranges from $19 \%$ to $55 \%$ for different age-groups and communities with a prevalence of $33.8 \%$ in Hong Kong. ${ }^{1-4}$ It has a significant adverse impact on quality of life for $12 \%$ of women with the condition in Hong Kong. ${ }^{3-5}$ Surgical treatment with tension-free vaginal tape
(TVT) is a known effective and durable procedure for patients in whom conservative treatment with pelvic floor exercises is unsuccessful. ${ }^{6}$ Retropubic TVT was first introduced in 1996 and long-term follow-up success rates of up to $77 \%$ have been reported 11 years after the procedure. ${ }^{6}$ However, TVT is associated with risk of bladder, urethra and vessel injuries, and voiding dysfunction. ${ }^{7}$ The development of transobturator TVT (TO-TVT) 
因壓力性尿失禁接受經閉孔無張力陰道懸吊手 術, 及同時接受骨盆底手術的女性的療效評估： 術後五年跟進報告

\author{
羅思敏、張優嘉、鍾國衡、陳丞智
}

目的：比較因壓力性尿失禁接受經閉孔無張力陰道懸吊手術, 及同時 接受骨盆底手術兩組婦女術後五年的主觀性及客觀性療效評估。

設計：前瞻性隊列研究。

安排：香港一所大學教學醫院的泌尿婦科部門。

患者：218名婦女於2004年9月至2009年12月期間接受經閉孔無張力 陰道懸吊手術 ; 其中96名 (44\%) 婦女只接受經閉孔無張力陰道懸吊 手術, 另 122 名 ( $56 \%$ ) 婦女因骨盆內器官膨出而同時接受骨盆底手 術。

主要結果測量：於手術後五年作出主觀性及客觀性療效評估。主觀性 根治的定義為在日常生活中沒有尿失禁的情況; 客觀性根治的定義為 於尿動力學檢查時沒有尿失禁的情況。

結果 : 對 88 名只接受經閉孔無張力陰道懸吊手術的婦女及 101 名同時 接受骨盆底手術的婦女隨訪五年。比較只接受經閉孔無張力陰道懸吊 手術的婦女及同時接受骨盆底手術的婦女, 其主觀性根治率分別為 $70.5 \%$ 及 $94.1 \%(\mathrm{P}<0.01)$ ；其客觀性根治率分別為 $80.3 \%$ 及 $85.7 \%$ $(\mathrm{P}=0.58)$ 。

結論：無論單一進行經閉孔無張力陰道懸吊手術或同時進行骨盆底手 術, 經閉孔無張力陰道懸吊手術治療壓力性尿失禁於術後五年仍能達 到高治癒率及同等根治療效。與只是進行單一經閉孔無張力陰道懸吊 手術比較, 同時進行骨盆底手術至少能達至相同的療效。

reduced the rate of complications with comparable efficacy to retropubic TVT in the short term. ${ }^{8}$ Such technique is now the first choice for the surgical treatment of USI.

Nearly $40 \%$ of women with pelvic organ prolapse (POP) have symptoms of USI and they often receive both continence surgery and pelvic floor repair (PFR) surgery at the same time. Yip and Pang ${ }^{9}$ compared women who underwent retropubic TVT with or without concomitant PFR surgery and concluded that TVT was equally effective with or without concomitant surgery for treatment of USI in women in Hong Kong. There is, however, little information on the efficacy of TO-TVT in this group of women.

The primary outcome of this study was to assess the objective and subjective cure rates at 1 and 5 years after operation in women with USI who received TO-TVT performed alone versus those who received TO-TVT with concomitant PFR surgery for POP. The secondary outcome was to compare any long-term complications of TO-TVT in both groups of women.

\section{Methods}

This was a prospective study involving all women with USI presenting to the out-patient clinic of a university hospital. All data were collected prospectively and input to a database established in 1996. There were 218 women with USI who received TO-TVT between 1 September 2004 and 31 December 2009. Ethics approval was obtained from the Institutional Review Board to conduct multifaceted analysis of this database (Clinical Research Ethics: CRE-2009.080).

Demographic information was obtained from all women with USI, followed by physical examination, including the standard POP quantification assessment, in the out-patient clinic. All women underwent standard urodynamic investigation, including uroflowmetry and filling and voiding cystometry following standards published by the International Continence Society ${ }^{10}$ with a Dantec Menuet (from 2004-2009; Dantec Medical A/S, Skovlunde, Denmark) or Maquet Radius (from 20092013; Maquet GmbH \& Co. KG, Rastatt, Germany) multichannel urodynamic machine.

Women with USI who did not improve after pelvic floor exercise were offered TO-TVT. ${ }^{5}$ Women who had USI only underwent TO-TVT surgery, while women with both USI and POP received TO-TVT and concomitant PFR surgery. Vaginal hysterectomy and anterior or posterior colporrhaphy were performed accordingly as PFR surgery. Women with a history of predominant detrusor overactivity (DO), previous continence procedures, or transvaginal mesh repair for POP were excluded from the study. Women with mental incapacity were also excluded.

Women had either TOT (outside-in technique; Monarc Subfascial Hammock, American Medical Systems Inc., Minnetonka [MN], US) performed from September 2004 to June 2006 or TVT-O (inside-out technique; Gynecare TVT obturator system, Ethicon Inc [NJ], US) performed from July 2006 to December 2009 in the same urogynaecology centre. The change from TOT to TVT-O was because TVT-O was becoming available. In this study, 124 women underwent TOT and 94 women underwent TVT-O. Cheung et $\mathrm{al}^{11}$ reported TOT and TVT-O had high and similar subjective and objective efficacy (81\%-84\%). All procedures were performed or supervised by a urogynaecologist according to the original techniques. ${ }^{12,13}$ Cystoscopy was performed after the procedure to identify any bladder or urethral injury. The urinary catheter was removed the next day, voiding volume and pattern was reviewed, and post-voiding residual urine was measured. Women were discharged if residual urine was less than $100 \mathrm{~mL}$.

Women were followed up 2 months after operation and then reviewed annually for 5 years. They were assessed subjectively by asking whether their USI symptoms became 'better', 'same', or 'worse'. If there was no urine leakage when performing 
physical activities, the women were regarded as having 'subjective cure' of the USI. Those who responded 'better' but had persistent or recurrent USI symptoms were regarded as 'subjective better', irrespective of the frequency and amount of urinary leakage. Patients were asked whether they had voiding difficulty, urgency, groin or vaginal pain, or dyspareunia. Physical examination was conducted to check for POP and vaginal tape erosion. Urodynamic study was repeated at 1 and 5 years to assess the objective outcome. Severity of USI was classified according to the degree of urine leakage in the cough stress test: mild (following a series of coughs), moderate (with a few coughs), and marked (with a single cough). Objective cure was defined as no urine leakage upon coughing during urodynamic study. The cough stress test is a well-established test for USI with sensitivity of $98 \%$ and specificity of $100 \% .^{14}$ However, there was no standard set to categorise the severity of USI during urodynamic study. Thus, cough stress test was used to further categorise the severity of USI. Detrusor overactivity was defined as occurrence of involuntary detrusor contractions of

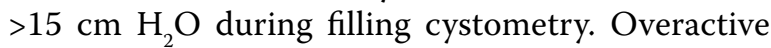
bladder (OAB) was defined as urinary urgency, usually accompanied by frequency and nocturia, with or without urgency urinary incontinence, in the absence of urinary tract infection or other obvious pathology. ${ }^{10}$ Patients who did not return for followup were contacted and offered another appointment. If they defaulted again, they were interviewed over the telephone using the same set of questions to assess subjective outcome. Follow-up would be ceased if there was no significant problem after the 5-year follow-up.

Data were analysed using the Statistical Package for the Social Sciences (Windows version 17.0; SPSS Inc, Chicago [IL], US). Descriptive statistics of data were presented as mean \pm standard deviation or number (\%). Categorical variables were compared using Chi squared test or Fisher's exact test. Continuous variables were compared using independent sample $t$ test. A P value of $<0.05$ was considered statistically significant.

\section{Results}

Of 218 women who underwent TO-TVT between 1 September 2004 and 31 December 2009, 96 (44\%) women had USI only and underwent TO-TVT alone, while 122 (56\%) women had USI and POP and underwent TO-TVT with concomitant PFR surgery. The PFR surgery was usually vaginal hysterectomy with anterior colporrhaphy. For preoperative data (Table 1), women who underwent TO-TVT and PFR surgery were older (mean, 65.6 vs 54.3 years; $\mathrm{P}<0.01$ ), had higher parity (mean, 3.9 vs 2.6 ; $\mathrm{P}<0.01$ ), and had more DO (11.5\% vs $2.1 \% ; \mathrm{P}=0.02)$.

At 1 year after surgery, 197 (90.4\%) women were reviewed at follow-up and 186 (85.3\%) had urodynamic study. At 5 years, 189 (86.7\%) women were either reviewed at follow-up or contacted by telephone (20 women) and 122 (56.0\%) had urodynamic study. The mean follow-up times were similar: $59.3 \pm 8.0$ months for the TO-TVT group and $58.6 \pm 8.0$ months for the TO-TVT with concomitant PFR surgery group.

The subjective cure rate at 1 year was $78.0 \%$ for

TABLE I. Patients' demographics

\begin{tabular}{|c|c|c|c|c|}
\hline \multirow[t]{2}{*}{ Demographics } & \multicolumn{3}{|c|}{ Mean \pm SD or No. $(\%)$} & \multirow[t]{2}{*}{$P$ value } \\
\hline & All $(n=218)$ & TO-TVT $(n=96)$ & $\begin{array}{l}\text { TO-TVT with concomitant } \\
\text { PFR surgery }(n=122)\end{array}$ & \\
\hline Age (years) & $60.5 \pm 12.7$ & $54.3 \pm 10.6$ & $65.6 \pm 11.9$ & $<0.01$ \\
\hline Body mass index $\left(\mathrm{kg} / \mathrm{m}^{2}\right)$ & $25.2 \pm 3.9$ & $25.4 \pm 3.6$ & $25.3 \pm 4.2$ & 0.80 \\
\hline Menopause & $146(67.0)$ & $47(49.0)$ & $99(81.1)$ & $<0.01$ \\
\hline No. of vaginal births & $3.3 \pm 1.8$ & $2.6 \pm 1.4$ & $3.9 \pm 1.9$ & $<0.01$ \\
\hline Biggest birth weight (kg) & $3.4 \pm 0.7$ & $3.4 \pm 0.8$ & $3.3 \pm 0.6$ & 0.33 \\
\hline Previous prolapse surgery & $4(1.8)$ & $1(1.0)$ & $3(2.5)$ & 0.40 \\
\hline Previous hysterectomy & $10(4.6)$ & $4(4.2)$ & $6(4.9)$ & 0.53 \\
\hline Preoperative OAB syndrome & $71(32.6)$ & $35(36.5)$ & $36(29.5)$ & 0.37 \\
\hline Preoperative DO & $16(7.3)$ & $2(2.1)$ & $14(11.5)$ & 0.02 \\
\hline \multicolumn{5}{|l|}{ Type of TVT } \\
\hline TOT & $124(56.9)$ & $51(53.1)$ & $73(59.8)$ & 0.39 \\
\hline TVT-O & 94 (43.1) & 45 (46.9) & 49 (40.2) & 0.39 \\
\hline
\end{tabular}

Abbreviations: DO = detrusor overactivity; OAB = overactive bladder; PFR = pelvic floor repair; $\mathrm{SD}=$ standard deviation; TO-TVT = transobturator TVT;TOT = outside-in technique of TVT;TVT = tension-free vaginal tape;TVT-O = inside-out technique ofTVT 
TABLE 2. Subjective and objective outcomes at I-year and 5-year follow-ups

\begin{tabular}{|c|c|c|c|c|c|c|c|c|}
\hline \multirow[t]{2}{*}{ Outcome } & \multicolumn{4}{|c|}{ 1-Year follow-up, No. (\%) } & \multicolumn{4}{|c|}{ 5-Year follow-up, No. (\%) } \\
\hline & Total & TO-TVT only & $\begin{array}{l}\text { TO-TVT with } \\
\text { concomitant } \\
\text { PFR surgery }\end{array}$ & $P$ value & Total & TO-TVT only & $\begin{array}{l}\text { TO-TVT with } \\
\text { concomitant } \\
\text { PFR surgery }\end{array}$ & $P$ value \\
\hline Subjective & $\mathrm{n}=197 / 218(90.4)$ & $n=91 / 96(94.8)$ & $\mathrm{n}=106 / 122$ (86.9) & & $n=189 / 218(86.7)$ & $\mathrm{n}=88 / 96(91.7)$ & $\mathrm{n}=101 / 122(82.8)$ & \\
\hline \multicolumn{9}{|l|}{ USI } \\
\hline Cure & $163(82.7)$ & $71(78.0)$ & $92(86.8)$ & 0.15 & $157(83.1)$ & $62(70.5)$ & $95(94.1)$ & $<0.01$ \\
\hline Better & $25(12.7)$ & $16(17.6)$ & $9(8.5)$ & 0.09 & $21(11.1)$ & $17(19.3)$ & $4(4.0)$ & $<0.01$ \\
\hline Same & $7(3.6)$ & $3(3.3)$ & $4(3.8)$ & 0.58 & $9(4.8)$ & $7(8.0)$ & $2(2.0)$ & 0.11 \\
\hline Worse & $2(1.0)$ & $1(1.1)$ & $1(0.9)$ & 0.71 & $2(1.1)$ & $2(2.3)$ & 0 & 0.42 \\
\hline De-novo OAB & $20(10.2)$ & $10(11.0)$ & $10(9.4)$ & 0.90 & $39(20.6)$ & $20(22.7)$ & $19(18.8)$ & 0.62 \\
\hline Objective & $n=186 / 218(85.3)$ & $\mathrm{n}=83 / 96(86.5)$ & $n=103 / 122(84.4)$ & & $\mathrm{n}=122 / 218(56.0)$ & $n=66 / 96(68.8)$ & $\mathrm{n}=56 / 122(45.9)$ & \\
\hline \multicolumn{9}{|l|}{ USI } \\
\hline No & $157(84.4)$ & $67(80.7)$ & $90(87.4)$ & 0.29 & $101(82.8)$ & $53(80.3)$ & $48(85.7)$ & 0.58 \\
\hline Mild & $10(5.4)$ & $6(7.2)$ & $4(3.9)$ & 0.49 & $5(4.1)$ & $3(4.5)$ & $2(3.6)$ & 1.00 \\
\hline Moderate & $10(5.4)$ & $4(4.8)$ & $6(5.8)$ & 1.00 & $6(4.9)$ & $4(6.1)$ & $2(3.6)$ & 0.70 \\
\hline Severe & $9(4.8)$ & $6(7.2)$ & $3(2.9)$ & 0.30 & $10(8.2)$ & $6(9.1)$ & $4(7.1)$ & 0.95 \\
\hline De-novo DO* & $10(5.4)$ & $5(6.0)$ & $5(4.9)$ & 0.98 & $11(9.0)$ & $3(4.5)$ & $8(14.3)$ & 0.12 \\
\hline
\end{tabular}

Abbreviations: $\mathrm{DO}=$ detrusor overactivity; OAB = overactive bladder; PFR = pelvic floor repair; TO-TVT = transobturator tension-free vaginal tape; USI = urinary stress incontinence

* The denominator for the calculation of de-novo DO was based on the total number of women who had urodynamic study performed at the I-year and 5-year follow-ups

TABLE 3. Complications of transobturator tension-free vaginal tape 5 years after surgery

\begin{tabular}{|c|c|c|c|c|}
\hline \multirow[t]{2}{*}{ Complication } & \multicolumn{3}{|c|}{ No. (\%) } & \multirow[t]{2}{*}{$P$ value } \\
\hline & Total $(n=189)$ & $\begin{array}{c}\text { TO-TVT only } \\
(n=88)\end{array}$ & $\begin{array}{c}\text { TO-TVT with } \\
\text { concomitant PFR } \\
\text { surgery }(n=101)\end{array}$ & \\
\hline Tape erosion & $3(1.6)$ & $1(1.1)$ & $2(2.0)$ & 0.51 \\
\hline Voiding problem & $2(1.1)$ & $2(2.3)$ & 0 & 0.21 \\
\hline Groin pain & $1(0.5)$ & $1(1.1)$ & 0 & 0.47 \\
\hline
\end{tabular}

Abbreviations: PFR = pelvic floor repair;TO-TVT = transobturator tension-free vaginal tape years $(\mathrm{P}=0.04)$. None required second operation for their USI during the 5-year follow-up.

In the study group, $10.2 \%$ and $20.6 \%$ had de-novo $\mathrm{OAB}$ at 1 and 5 years, respectively, and there was no statistical difference between the TO-TVT group and TO-TVT with concomitant PFR surgery group. More women developed de-novo DO at 5 years in the TO-TVT with concomitant PFR surgery group compared with TO-TVT group (14.3\% vs $4.5 \% ; \mathrm{P}=0.12)$, although it did not reach statistical difference. Eight (8.3\%) women in the TO-TVT group with de-novo OAB required medical treatment for their symptoms and five (4.1\%) women in the TO-TVT with concomitant PFR surgery group required treatment $(\mathrm{P}=0.30)$.

No neurological complications resulting from the surgery were reported. Three women (two in the concomitant PFR surgery group and one in the TO-TVT alone group) had tape erosion requiring excision of the exposed tape (Table 3). The patients all presented with vaginal pain. The exposed tape was cut and the vaginal skin was repaired under local or regional anaesthesia. All three women had no recurrence of USI after tape excision at the 5-year follow-up. Two women (both from TO-TVT alone group) developed voiding difficulty with $O A B$ symptoms and the tape was cut at 4 months and 18 months after the operation, respectively. Their voiding problem was resolved and both had no recurrence of USI after tape release. One woman 
(in the TO-TVT alone group) had groin pain 4 years after the operation and was treated conservatively with analgesics.

\section{Discussion}

Transobturator TVT has been proven to be safe and highly effective, ${ }^{11,15}$ and has become a standard treatment for USI. Pelvic floor repair surgery is commonly performed at the same time as continence surgery. ${ }^{16}$ However, there is limited information comparing the long-term efficacy of TO-TVT in women with or without concomitant PFR surgery. This study evaluated 5-year subjective and objective outcomes in the two treatment groups of women with USI alone and those having USI and POP who required treatment for both conditions.

Women in the TO-TVT with concomitant PFR surgery group were older, had had a higher number of vaginal births, and more were menopausal and had DO. This observation is likely due to the age of the women, as risk of DO also increases with age and more women had pre-existing DO in this group.

Subjective cure in our study was defined as feeling completely dry after TO-TVT operation. The 5 -year subjective cure rate of the TO-TVT alone group was $70.5 \%$. Although this appears to be lower than in the concomitant PFR surgery group of $94.1 \%$, the result is comparable to most of the published data on long-term efficacy of TO-TVT. Angioli et $\mathrm{al}^{17}$ showed a $62 \%$ patient satisfaction rate and $73 \%$ objective success rate at 5 years. Abdel-Fattah et al ${ }^{18}$ also showed a $73 \%$ patient-reported success rate for TO-TVT at 3-year follow-up in 238 women.

We hypothesised that women with concomitant PFR surgery had a higher subjective cure rate because anterior colporrhaphy added an anti-incontinence effect. Furthermore, the main symptoms for this group of women might be related to POP so treating their POP could raise their overall satisfaction. Recurrence of POP may mask the symptoms of USI, but this hypothesis requires further analysis, as the recurrence rate of POP was not collected in this study. The above factors may account for the higher subjective cure rate observed, although the objective cure rates were high in both groups.

The 5-year overall subjective and objective cure rates were $83.1 \%$ and $82.8 \%$, respectively, which are similar to international figures. ${ }^{19,20}$ Athanasiou et al $^{19}$ reported 7 -year overall subjective and objective cure rates of $83.5 \%$ and $81.5 \%$, which included women who received TO-TVT alone or with concomitant PFR surgery, but there was no statistical comparison between the groups. Tsivian et $\mathrm{al}^{20}$ reported $82.9 \%$ versus $85.2 \%$ continence rates in patients undergoing TO-TVT alone versus those who received concomitant vaginal surgery at a mean follow-up period of up to 3 years. These studies, however, were either small or had short follow-up durations.

The long-term complication rate of TO-TVT is low. The most commonly encountered morbidity was de-novo DO after TO-TVT ( $9 \%$ at 5 years), which is similar to that reported in the literature. ${ }^{17,19}$ Athanasiou et $\mathrm{al}^{19}$ reported $7 \%$ de-novo urgency 7 years after TVT-O and Angioli et $\mathrm{al}^{17}$ found a 5 -year de-novo urgency rate of $6.4 \%$. The higher percentage of women developing de-novo DO at 5 years $(9.0 \%)$ when compared with 1 year $(5.4 \%)$ could be attributed to ageing. This difference also suggests that more women had de-novo DO in the prolapse group (14.3\%) than in the TO-TVT alone group (4.5\%) as the mean age of the prolapse group was higher. Our 5-year study also shows low rates of mesh erosion and voiding dysfunction after operation, and concomitant surgery does not impose higher complication rates.

We recommend TO-TVT with concomitant PFR surgery as the treatment of choice for women with symptomatic POP and USI. A recent metaanalysis showed a reduced risk of postoperative USI after combination surgery (mid-urethral sling with prolapse surgery) relative to prolapse surgery alone (5\% vs $23 \%$ ) for women with prolapse and symptomatic USI. ${ }^{21}$ In asymptomatic women with prolapse, however, only $7 \%$ required subsequent surgery for de-novo USI. Therefore, even with the promising result of combination surgery, it should only be performed in symptomatic incontinent women instead of as routine surgery for all women with prolapse because TO-TVT is not a risk-free procedure. Thus, preoperative evaluation of urinary symptoms and urodynamic study still plays a role in individual treatment planning.

There are limitations in this study. This was not a randomised controlled study and there was lack of blinding when assessing the objective outcomes. There were significant differences between the characteristics of the two groups (Table 1), and further randomised study is warranted to find out whether those factors contribute to the differences observed in subjective outcomes. We lacked a detailed questionnaire to evaluate the subjective cure rate and to assess quality-of-life aspect after the operation. The validated questionnaires in Chinese were only available after the study period. ${ }^{22,23}$ However, our previous study has confirmed the improvement in quality of life of women receiving continence surgery with or without PFR surgery. ${ }^{24}$ Although the response rate for subjective outcome measure was high at 5 years (overall response, $86.7 \%$ ), fewer women (56.0\%) returned for objective assessment using urodynamic study at 5 years.

\section{Conclusions}

Transobturator TVT is an effective treatment for USI 
in women who received it alone or with concomitant PFR surgery. This technique provides high subjective and objective efficacy for up to 5 years with a good safety profile. Transobturator TVT with concomitant PFR surgery achieved similar, if not better, long-term outcomes when compared with TO-TVT alone.

\section{References}

1. Zhu L, Lang J, Liu C, Han S, Huang J, Li X. The epidemiological study of women with urinary incontinence and risk factors for stress urinary incontinence in China. Menopause 2009;16:831-6.

2. Thom D. Variation in estimates of urinary incontinence prevalence in the community: effects of differences in definition, population characteristics, and study type. J Am Geriatr Soc 1998;46:473-80.

3. Pang MW, Leung HY, Chan LW, Yip SK. The impact of urinary incontinence on quality of life among women in Hong Kong. Hong Kong Med J 2005;11:158-63.

4. Cheung RY, Chan S, Yiu AK, Lee LL, Chung TK. Quality of life in women with urinary incontinence is impaired and comparable to women with chronic diseases. Hong Kong Med J 2012;18:214-20.

5. Fan HL, Chan SS, Law TS, Cheung RY, Chung TK. Pelvic floor muscle training improves quality of life of women with urinary incontinence: a prospective study. Aust N Z J Obstet Gynaecol 2013;53:298-304.

6. Nilsson CG, Palva K, Rezapour M, Falconer C. Eleven years prospective follow-up of the tension-free vaginal tape procedure for treatment of stress urinary incontinence. Int Urogynecol J Pelvic Floor Dysfunct 2008;19:1043-7.

7. Boustead GB. The tension-free vaginal tape for treating female stress urinary incontinence. BJU Int 2002;89:68793.

8. Agur W, Riad M, Secco S, et al. Surgical treatment of recurrent stress urinary incontinence in women: a systematic review and meta-analysis of randomised controlled trials. Eur Urol 2013;64:323-36.

9. Yip SK, Pang MW. Tension-free vaginal tape sling procedure for the treatment of stress urinary incontinence in Hong Kong women with and without pelvic organ prolapse: 1-year outcome study. Hong Kong Med J 2006;12:15-20.

10. Haylen BT, de Ridder D, Freeman RM, et al. An International Urogynecological Association (IUGA)/ International Continence Society (ICS) joint report on the terminology for female pelvic floor dysfunction. Neurourol Urodyn 2010;29:4-20.

11. Cheung RY, Chan SS, Yiu KW, Chung TK. Inside-out versus outside-in transobturator tension-free vaginal tape: a 5-year prospective comparative study. Int J Urol
2014;21:74-80.

12. Jonsson Funk M, Levin PJ, Wu JM. Trends in the surgical management of stress urinary incontinence. Obstet Gynecol 2012;119:845-51.

13. Olsson I, Abrahamsson AK, Kroon UB. Long-term efficacy of the tension-free vaginal tape procedure for the treatment of urinary incontinence: a retrospective follow-up 11.5 years post-operatively. Int Urogynecol J 2010;21:679-83.

14. Swift SE, Yoon EA. Test-retest reliability of the cough stress test in the evaluation of urinary incontinence. Obstet Gynecol 1999;94:99-102.

15. Houwert RM, Renes-Zijl C, Vos MC, Vervest HA. TVT-O versus Monarc after a 2-4-year follow-up: a prospective comparative study. Int Urogynecol J 2009;20:1327-33.

16. Bai SW, Jeon MJ, Kim JY, Chung KA, Kim SK, Park KH. Relationship between stress urinary incontinence and pelvic organ prolapse. Int Urogynecol J Pelvic Floor Dysfunct 2002;13:256-60; discussion 260.

17. Angioli R, Plotti F, Muzii L, Montera R, Panici PB, Zullo MA. Tension-free vaginal tape versus transobturator suburethral tape: five-year follow-up results of a prospective, randomised trial. Eur Urol 2010;58:671-7.

18. Abdel-Fattah M, Mostafa A, Familusi A, Ramsay I, N'dow J. Prospective randomised controlled trial of transobturator tapes in management of urodynamic stress incontinence in women: 3-year outcomes from the Evaluation of Transobturator Tapes study. Eur Urol 2012;62:843-51.

19. Athanasiou S, Grigoriadis T, Zacharakis D, Skampardonis $\mathrm{N}$, Lourantou D, Antsaklis A. Seven years of objective and subjective outcomes of transobturator (TVT-O) vaginal tape: why do tapes fail? Int Urogynecol J 2014;25:219-25.

20. Tsivian A, Benjamin S, Tsivian M, et al. Transobturator tape procedure with and without concomitant vaginal surgery. J Urol 2009;182:1068-71.

21. van der Ploeg JM, van der Steen A, Oude Rengerink K, van der Vaart $\mathrm{CH}$, Roovers JP. Prolapse surgery with or without stress incontinence surgery for pelvic organ prolapse: a systematic review and meta-analysis of randomised trials. BJOG 2014;121:537-47.

22. Chan SS, Cheung RY, Yiu AK, et al. Chinese validation of Pelvic Floor Distress Inventory and Pelvic Floor Impact Questionnaire. Int Urogynecol J 2011;22:1305-12.

23. Chan SS, Choy KW, Lee BP, et al. Chinese validation of Urogenital Distress Inventory and Incontinence Impact Questionnaire short form. Int Urogynecol J 2010;21:807-12.

24. Chan SS, Cheung RY, Lai BP, Lee LL, Choy KW, Chung TK. Responsiveness of the Pelvic Floor Distress Inventory and Pelvic Floor Impact Questionnaire in women undergoing treatment for pelvic floor disorders. Int Urogynecol J 2013;24:213-21. 